\title{
COMPLEX PARTIAL STATUS EPILEPTICUS IN A CHILD
}

\author{
DÉLRIO F. SILVA*, EDMAR ZANOTEL ${ }^{* \star}$, MÁRCIA MAROUES LIMA***, \\ RENATO ANGHINAH***, JOSÉ GERALDO CAMARGO LIMA****
}

SUMMARY - Complex partial status epilepticus (SE) has been reported rarely in children. We describe the clinical case of a 14 year-old girl with complex partial seizures (CPS) since age 10 who developed a complex partial SE probably because she was not adherent to treatment. The neurologic examination and computed tomography scan were normal. During the SE she received diazepam and phenytoin and became free of the seizures after 5 minutes. The ictal EEG showed spikes and slow waves over the right temporal region.

KEY WORDS: complex partial status epilepticus, EEG, child.

\section{Estado de mal epiléptico por crise parcial complexa em uma criança}

RESUMO - Estado de mal epiléptico por crise parcial complexa tem sido raramente referido em crianças. Relatamos o quadro clínico de uma menina com 14 anos de idade, com crises parciais complexas desde os 10 anos e que desenvolveu estado de mal epiléptico por crises parciais complexas, provavelmente por não ser aderente ao tratamento. O exame neurológico e a tomografia computadorizada de crânio foram normais. Durante o estado de mal epiléptico ela recebeu fenitoina e diazepam e ficou livre das crises após 5 minutos. O EEG ictal mostrou espículas e ondas lentas na região temporal direita.

PALAVRAS-CHAVE: estado de mal epiléptico, crise parcial complexa, EEG, criança.

Complex partial seizures is the most frequent form of partial epilepsy in adults" ${ }^{2}$, but the status epilepticus (SE) is uncommom ${ }^{11,18}$, and if it occur in children, it is much more rare ${ }^{4,8,8,19,20}$. We have found few publications of complex partial SE, with a total of 14 cases $^{3,12,13,16}$.

Our objetive in this paper is to report a clinical case of this situation in a child.

\section{CASE REPORT}

ASS, a fernale child, was first seen at the age of 14 years when she was referred with a history of numerous daily attacks of blank spells. She was hospitalized for investigation and treatment. The antenatal and birth histories had been unremarkable. There was no history of consanguinity or family history of seizures. In retrospect, the parents felt that she had been having staring spells from the age of 10 years when the treatment begun but she was not adherent. These spells lasted less than $3 \mathrm{~min}$ and were associated with alimentary (chewing, lip and tongue smacking, swallowing, or licking one's lips) and gestual automatisms. Psychomotor development was normal. Her performance in school was good. During the examination she used to stare with fixed gaze and frozen face, periods of confusion and we observed characteristic automatisms that consisted mainly of grasping objects and frightened expression.

* Head of the EEG Sector, Escola Paulista de Medicina (EPM); **Resident in Neurology; ***Junior Doctor of the EEG Sector; **** Full Professor and Head of the Discipline of Neurology, EPM. Aceite: 2janeiro-1995.

Dr. Délrio Façanha da Silva - Disciplina de Neurologia, Setor de Eletrencefalografia, Escola Paulista de Medicina - Rua Botucatu 740 - 04023-900 São Paulo SP - Brasil. 


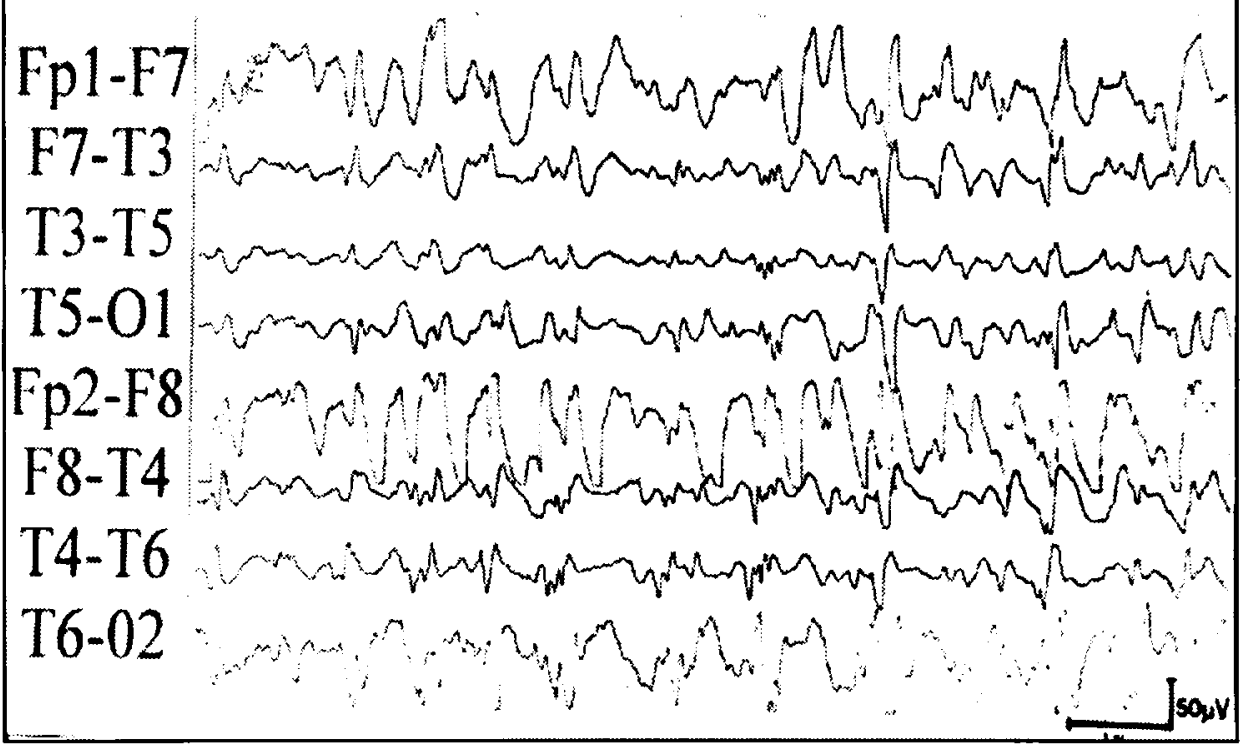

Fig I. EEG carried out during the complex partial status of our patient: continuous slow waves intermixed with spikes and sharp discharges over the right fronto-temporal region and with spread to the contralateral side.

$|p|-17$

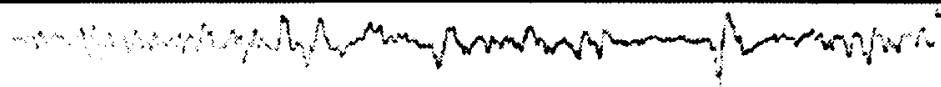
17-13…

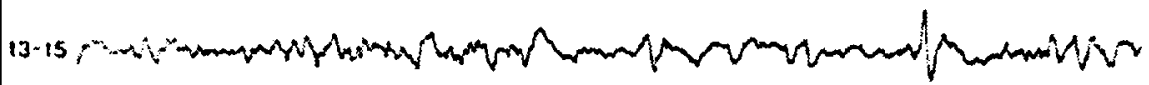

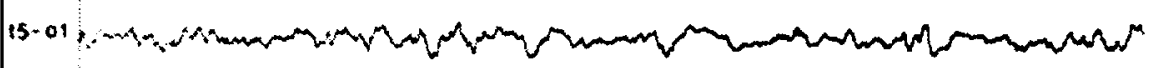
p2.18 2-

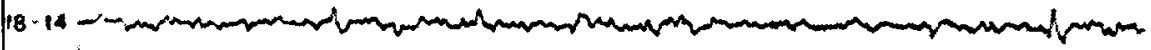

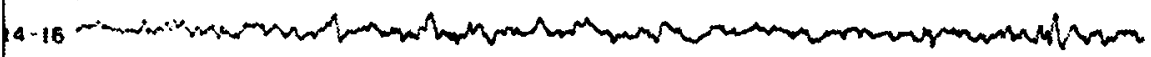
6.02

Fig 2. Interictal EEG: isolated and independent sharp waves over both anterior temporal regions. 
A conventional EEG (CEEG) was recorded for $30 \mathrm{~min}$ and showed continuous discharges characterized by slow waves intermixed with spike and sharp components in various degrees over the right fronto-temporal region with spread to contralateral region (Fig 1). A diagnosis of complex partial SE was made, and she was treated with diazepam and phenytoin. Clinical events were not observed after initiation of treatment. A second CEEG was recorded, at which time she had been seizure-free for 2 hours. This recording showed a normal background activity and interictal paroxysmal discharges by isolated sharp waves independently over both fronto-temporal regions but with a predominance on the left side (Fig 2). Physical and neurological examination were normal. Computed tomography scan was also normal.

Following discharge from hospital, the girl was seen at regular intervals as an outpatient and, at age 15 , while on carbamazepine therapy, she improved of the seizures, exhibiting a frequency of 12 to 16 per year.

\section{COMMENTS}

The variable clinical expression and the need of EEG for confirmation become very difficult, sometimes, the recognition of complex partial SE. The first case was published by Gastaut and Roger $(1956)^{7}$ and has previously been considered a rare phenomenon, but the actual incidence of this disorder may be underestimated ${ }^{1,12,14}$. Temporal lobe SE and psychomotor SE are the other terms that have been used to describe this phenomenon ${ }^{10}$, but is not an appropriate designation, since seizures emanating from extratemporal regions may be associated with complex partial SE ${ }^{14,17}$.

Several criteria for diagnosis of complex partial SE have been proposed. Mayeux and Lueders ${ }^{12}$ stressed focal EEG epileptic discharges, either continuous or recurrent, while Treiman and DelgadoEscueta $^{15}$ emphasized recurrent or cyclical behavioural seizures. Our patient illustrates well the continuous type. It is our opinion that this classification into discontinuous and continuous forms is purely descritive, and transitions from one to the other type may exist.

The ictal EEG in our patient showed discharges arising in the right temporal region, confirming the diagnosis of complex partial SE. The majority of the previously reported cases were, also, of temporal origin ${ }^{3,13}$, but a few had an occipital focus ${ }^{6}$. Moreover the features of complex partial SE were consistent in our patient. The patient had impaired consciousness characterized by absence of vocalization, lack of interaction with familiar people, decreased reaction to pain, and intermitent picking at clothing or nearby objects. The episode was terminated after 5 minutes to 1 hour by intravenous anticonvulsant medication (diazepam and phenytoin).

It is important the differential diagnosis between absence status and complex partial SE because the choice of treatment; however, this differentiation, sometimes, may be difficult. Absence status comprised all cases of nonconvulsive SE, except those in which a focality could be shown in the EEG $^{2,6}$, as in our patient. Thus, it is obvious that the clinical characteristics alone do not allow an unequivocal differentiation between these two entities. The risk of misdiagnosing a complex partial SE as absence status, therefore remains, unless an EEG of the initial phase of the status is obtained.

\section{REFERENCES}

1. Ballenger CE, King DW, Gallagher BB. Partial complex status epilepticus. Neurology 1983, 33:1545-1552.

2. Cascino GD. Nonconvulsive status epilepticus in adults and children. Epilepsia 1993, 34 (Suppl 1):S21-S28.

3. Doose H. Nonconvulsive status epilepticus in childhood: clinical aspects and classification. In DelgadoEscueta AV, Wasterlain CG, Treiman DM, Porter RJ (eds). Status epilepticus. Advances in Neurology, vol 34. New York: Raven Press, 1983, p 83-92.

4. Duchowny MS. Complex partial seizures of infancy. Arch Neurol 1987, 44:911-914.

5. Duchowny MS, Levin BE. Hemispheric lateralization of complex partial seizures in infancy: implications for development (Abstr). Neurology 1986, 36(Suppl 1):S191.

6. Gastaut H. Classification of status epilepticus. In Delgado-Escueta AV, Wasterlain CG, Treiman DM, Porter RJ (eds). Status epilepticus. Advances in neurology, vol 34. New York: Raven Press, 1983, p 15-35.

7. Gastaut H, Roger A. Sur la signification de certain fugues épileptiques: état de mal temporal. Rev Neurol 1956, 4:298-301. 
8. Holmes GL. Partial complex seizures in children: an analysis of 69 seizures in 24 patients using EEG FM radiotelemetry and videotape recording. Electroenceph Clin Neurophysiol 1984, 57:13-20.

9. Jensen I. Temporal lobe epilepsy: types of seizures, age and surgical results. Acta Neurol Scand 1976, 53:335-357.

10. Lugaresi E, Pazzaglia P, Tassinari CA. Differentiation of "absence status" and "temporal lobe status". Epilepsia 1971, 12:77-87.

11. Markand ON, Wheeler GL, Pollack SL. Complex partial status epilepticus (psychomotor status). Electroenceph Clin Neurophysiol, 1978, 44:125-126.

12. Mayeux R, Lueders H. Complex partial status epilepticus: case report and proposal for diagnostic criteria. Neurology 1978, 28:957-961.

13. McBride MC, Dooling EC, Oppenheimer EY. Complex partial status epilepticus in young children. Ann Neurol 1981, 9:526-530.

14. Tomsom T, Svanborg E, Wedlund JE. Nonconvulsive status epilepticus: high incidence of complex partial status. Epilepsia 1986, 27:276-285.

15. Treiman DM, Delgado-Escueta AV. Complex partial status epilepticus. In Delgado-Escueta AV, Wasterlain CG, Treiman DM, Porter RJ (eds). Status epilepticus. Advances in neurology, vol 34. New York: Raven Press, 1983, p 69-81.

16. Williams D. The structure of emotions reflected in epileptic experiences. Brain 1956, 79:29-67.

17. Williamson PD, Spencer DD, Spencer SS, Novelly RA, Mattson RH. Complex partial status epilepticus: a depth-electrode study. Ann Neurol 1985, 18:647-654.

18. Wolf P. Zur Klinik und Psychopathologie des Status psychomotoricus. Nervenarzt 1970, 41:603-610.

19. Wyllie E, Chee M, Granstrom ML, DelGiudice E, Estes M, Comair Y, Pizzi M, Kotagal P, Bourgeois B, Luders H. Temporal lobe epilepsy in early childhood. Epilepsia 1993, 34:859-868.

20. Yamamoto N, Watanabe K, Negoro T, Takaesu E, Aso K, Furune S, Takahashi I. Complex partial seizures in children: ictal manifestations and their relation to clinical course. Neurology 1987, 37:1379-1382. 